and he could taste the darkness that weighed down on his face. Roll with the punch, swim with the tide. . . He put his face against the cold metal of the bars and relaxed the muscles in his body. What would they do with him? He pissed like an infant, warm and free, down his leg, swimming with the tide.

\title{
Nuestra Senora, Reina de Los Angeles
}

\section{Peter Israel}

She climbed from the white Mercedes. Through the window he watched her body bunch, then straighten before she launched up his path. If portraits were his line, he thought, he might paint one like that: big Venus on the half shell at middle age, bigger than Botticelli's. He'd blow her hair loose with a four-sided wind and strip the tweeds, let the shell crack.

He stopped working. The front door opened without a knock. He caught a brief glimpse of himself in blue coveralls, then she sailed into his studio like a judge at a county horseshow.

"Please leave me alone," she said after a few amenities. "I don't look at art in the presence of the artist."

By the kitchen sink he asked the pitcher: Don't or won't?, but the pitcher lacked ears. It stared back at him dumbly through eyes he'd added to either side of its beak. He might knock, and ask her. Please leave me alone, she said to him curtly, I'm looking at horses. He filled the pitcher to the brim and stepped past the sliding door of the living room into the dirt backyard with the view of the Santa Monica Mountains and the car graveyard. Every artist ought to experience Los Angeles, he'd decided, the brown haze rising off the brown hills like bad breath, the creep of detritus over the landscape. . . .

He couldn't remember when he'd watered the plants last. Cactus no more than once a week, someone had told him, too much water killed the cactus. Nothing else did. 
Maybe she was adding a few touches of her own, a vermilion stroke in the withers. Easy when you knew the secret. He could use a little coaching, he supposed.

If she'd told him in advance, he could have lent her a smock.

He emptied the pitcher into the gardenias and left the cactus dry.

He returned to the living room, heard nothing. Pitcher in hand, he eyed the canvases on the walls. Aside from the canvases which filled the wall space, table in the kitchen nook, comfortable chair, two pole lamps, California carpet, the room was bare. It was OK with him, he was only passing through. She ought to look at these, he thought, the old stuff, at least they were over and done with. One room for painting, one for paintings, one for himself, 90 bucks a month, no air-conditioning but a view. He'd had bigger and smaller, cheaper. The light wasn't bad.

He tiptoed to the door, heard nothing. Time's up, Senora, he said, I've watered the plants. He turned the knob, and stopped on the threshold.

She was standing a few paces in front of his easel, her back to him, her shoulders heavy and erect. Her legs were apart, the left foot slightly to the front of the right. Her hands hung long by her sides. Yes, he said, not moving, you could have at least have pulled the drapes, your chauffeur might see. He smelled her. She was naked as the day she was born.

Well.

His eyes flicked over the work hanging and leaning. Nothing had been changed that he could see. Her clothes lay folded neatly over the wood chair, hose drooping empty toward the shoes with lips like old-fashioned cameos tucked by the chair legs. A touch of chic, he thought, the shoes, his eyes returning to the white melons of her ass glistening in the light.

She hadn't budged. She was looking at art.

He laughed, more a sigh than a laugh. Did she hear him? He was too old for this nonsense, wasn't she? He saw, though, that he'd misread the body. He'd expected it to fall apart once the cinches were unhooked. It didn't, and he saw no cinches. The melons looked cool to the touch. A sudden sense that he'd experienced it before pricked him, but he couldn't remember where or when.

He sighed again. She was a big and handsome bitch, this one, he had to give her that, as big as he and handsomer, big-boned, erect, with an ass of alabaster. Do you want it from the front, Senora, he asked, or the rear or do we have to wrestle first?

He heard her breathing regularly.

If they sat in opposite halves of a balance, which side would go up?

A car went by in the street.

He began a wide and quiet circle, as if studying a statue in a museum. The giddy sense of déjà-vu gusted in and out of his mind. He caught her heavy breasts in profile, the billow of her belly. Her eyes were gray, blue, green like sea, and unblinking. They paid him no attention.

“. . . have evolved," she was saying tonelessly, not turning her head. "The forms are evolving."

She dropped from view as he passed behind the easel, then reappeared on 
the far side, the light full on her. He stopped. She appeared to be waiting for him to move again.

He moved.

"It's good," she continued, "very."

One white arm lifted and pointed at the work on the wall.

"It's interesting the way the original forms have stretched out and elongated, circle into curve, curve into the column and the arch."

Her voice had lost its peremptory edge. The words came out dispassionately, with a faint husk to them.

Which came first, he asked, the circle or the arch?

The white arm fell back.

"Presumably you're approaching your resolution," she said, nodding toward the easel.

He completed his circle and stopped behind her, close but not touching, scanning the unfinished painting over her shoulder, conscious of the windless way her hair blew off the nape into a tangle. He saw no gray.

"It manages what you couldn't get before," she went on, "I'm not talking about the hand but the arches. They seem about to collide. That's when it resolves, when they collide and don't collide."

It could go either way, he thought distantly, arches were arches. That's the way he'd seen them somewhere, cloister arches perhaps, planes of arches out of planes of arches, ending in arches. blind.

Down through the arches, out of nowhere, reached the giant hand, groping

"I wonder why you're obsessed with the form," she said.

He'd worked for days on the hand, but the hand didn't interest her.

“. . . mastery of the white space," she was saying, “. . . see the white space in a way few painters ..."

He supposed he couldn't concentrate because he had his clothes on.

She fell silent. Maybe she was examining the white space. He heard her breathing. Lovely thing to tell a painter, that he'd mastered white space. Somehow in the quiet her body had closed on his without his noticing movement, so close he imagined the down standing on the alabaster cheeks. He felt a telltale prickle in his balls, like a faraway train.

"It's good," she said at last. "You've almost done. You always work in cycles, don't you."

It wasn't a question, a statement.

"Mmmm," he answered finally. Yes, he always did work in cycles.

She laughed low, an unexplained half-laugh.

Then abruptly, the spell broke. It happened so fast he remembered no transition. One second he was almost touching her, the next he stood alone while she began to dress, her gestures quick and economical like a model's.

In a daze he watched the garments slip from the chair one by one. Her shoulders flexed as she stooped, her heavy breasts swung free like fruit. The flesh of her belly folded and curled, one leg extended, then the other.

She shook her hair into place and turned, appraising him without expression, 
and then she left, quickly, like that, without a word.

He heard his front door shut. Her heels clicked on cement. Her chauffeur opened the rear door. She dipped, her skirt bulged taut, the door closed. The white Mercedes purred, and vanished.

He discovered he was still holding the pitcher. He put it down, put his hands in his coveralls and shook his head, like a dog out of a bath.

He sat down.

He exhaled slowly. His skin tingled still from the uncanny sense that he'd lived it all before.

"Where?" he said aloud.

No one answered.

He started to laugh. The sound echoed hollowly off the walls. His circles caught his eye, and the dark ovals, and the stately arches of the unfinished canvas on the easel. What was it she said, something about his obsession?

"I wonder why you're obsessed with the form."

I forgot to tell you, Senora, he replied, I'm a very religious man.

Why was it that his best lines always came to him when the pitcher was his only audience?

So you muffed it, he told himself, not the first time, what the hell?

What the hell what the hell? he answered angrily. What the hell had he been waiting for? If culture and sex was what the bitch wanted, then culture and sex was...

But he'd be damned. He was too old for the game, or too young.

"You ought to have a show, darling," that's what he'd been waiting for. As if he still needed to be discovered, at his age.

Yes, objectively he did.

Preoccupied, he squeezed paint onto the sheet of plate glass he used for a palette. He picked a brush from the peanut butter jar and began to muddle with it, reviewing the scene in his mind. She'd called in advance, she'd come, she'd stripped, she'd looked, as natural as taking a shit. She'd even talked about the work, which was better than most of the culture bitches he'd run into. Maybe the trouble with them was they didn't take their clothes off. Critics too, for that matter, and painters. Why did he wear the coveralls all the time like a goddam grease monkey?

He worked on the hand, concentrating on the thumb, until he realized that he was only pushing paint around. Probably all he needed was to get laid. It was easy for a painter, people believed, and therefore it was, sometimes. He wouldn't mind paying for it either, if he didn't have the shorts temporarily. He had nothing against whores.

In the night it came to him suddenly, like a dream forgotten and then remembered out of the blue. Forearms on his thighs, smoking on the wood chair he'd carried into the dirt backyard, he watched the smog filtering moonbeams onto the hills and the rocky heaps of cars, which he called Potter's Mountain. He was 
reliving the scene for the umpteenth time, and how she stood, legs apart, one foot slightly forward, arms loose, and how he circled her, like a statue in a museum, and ... that was it! The museum! The French book!

He started to giggle, in spite of himself. That had been his reaction when he'd read it. It was years ago, he thought, way back, it must have been in Paris in the days when no one else in the world knew he was a painter. What was the author's name? He couldn't remember the title either, only the author's extraordinary fantasy. He'd gone to a museum, this latterday marquis, and in some hidden recess had spied a woman studying a masterpiece. And coming up on her suddenly, he'd possessed her, and all the while he possessed her, she'd continued to gaze upon the masterpiece, impervious, oblivious . . .

Possess, that was the key irony, posséder!

Like a nun! he remembered, his chest shaking with laughter. That was it! The art lover in the museum, the nun in the cathedral, the whore in her brothelall three were alike, the writer said, all three went about their business with that singleminded concentration, that same tireless devotion, like . . .

Like in the morning, in his studio, Nuestra Senora.

And what if she'd screamed? he wondered. Suppose she screamed and the guards came running (or the chauffeur), what would the Frenchman have done? Well, if he'd been worth his French salt, he'd have proved to the satisfaction of his judges that it was all part and parcel of the esthetic experience.

But how?

That was the question.

"I don't know," he said out loud, "ask me in twenty years."

Very funny, he replied, the fact remains that you've blown it. How many chances did a man get to live out a fantasy? Trouble was, his studio didn't compare to a museum recess or a church, not that they were what they used to be either. The old reek, musty and dank, a little cunty in the corners, it gave a man ideas...

How did you fuck a nun in the act of praying?

You don't, he answered, you sell her candles. That was the point. He could use a little patronage, he had to admit it. His damned painterly arrogance had done him in again. He'd never gotten used to hustling buyers and sellers, it wasn't his way. Instead he traveled light, lighter as he went, taking what came. And sometimes, he reflected, not taking what came. Trouble was, he wasn't any younger. A man needed to worry about his dotage, even a painter, particularly a painter.

Maybe he ought to think about changing his system. He was used to working in one spot only as long as it took him to earn enough to move on. Sooner or later a gallery discovered him or a patron or both at once, and then he sold what he could, shipped the rest, followed it, established himself again. His needs were small, the work took most of his cash. Always he'd managed: to paint and get out when he was done, and he'd been all over America that way and much of the world.

He was a good painter, he sometimes thought, or very good. She'd been right, though, he did paint in cycles. Probably that was one of his mistakes. Journeymen 
were supposed to have trademarks, only Picassos could shed their skins whenever they felt like it. Well, he couldn't help it anyway, he worked his way through a phase of connected canvases, sometimes repeating himself almost exactly, in a cycle which took six months, or two years, or longer . . . and then he started again, in another place. Some critic had once called him a magic realist, another a painter's painter. The second had made him puke, literally.

And now he was master of the whites.

Well, the work got done. His needs were small, like his reputation. He'd shed countless skins. He'd even been married once or twice, he didn't remember, yes he did, but women were too much an encumbrance. He traveled light, as was his way, had to, liked it ...

His joints cracked as he rose. Maybe, impossible thought, she'd found him too old for her taste, too weighty in the legs. Through the coveralls he felt his stomach where it looped away from his chest, ran a hand through his hair.

He preferred his painterly arrogance. His arrogance, yes, his arrogance had done him in.

He could call her back.

He didn't call her. Instead, a few days later, she called him.

His stomach jumped when the phone rang. row?"

"I want to see your progress," her voice said distantly. "May I come tomor-

\section{“Tomorrow?"}

He hesitated. Her voice sounded odd to him, so did his own.

"Yes," he said, "tomorrow's OK, fine . . ." but he heard a click in the receiver, and whatever else he had to say stuck in his throat.

Such as: what shall I wear, Senora?

He laughed nervously. He felt a little like a student about to get his knuckles rapped. The fact was, his "progress" didn't amount to much. He'd changed the angle of the hand, twice, and kept his plants company. Now that he examined it again, it occurred to him that the hand would be called God's, or the artist's. He held his own against the canvas, flopped it back and forth until satisfied that the one had nothing to do with the other.

On the other hand, what did God's look like?

And since when was what they said his lookout?

He put his brushes to soak and went out walking. That was nothing new, he'd already tramped every inch of the neighborhood. It was a nondescript place. The sameness of the parallel lines oppressed him again, as they always did. For God's sake, why were Americans such a symmetrical breed? The whole country looked as if it came out of a manual. Everything went in rows: gutters, manholes, sidewalks, trees, mailboxes, lawns, housefronts, a man who had to walk his way out would lose his mind before he reached the first curve. Because, he'd guessed the secret, there were no curves. The country ran straight, from one end to the other.

But America wasn't bugging him. It couldn't, he was too used to it. $\mathrm{He}$ could walk America with his eyes closed and never stumble. America was Amer- 
ica was America America, it could take care of itself. He kept himself walking, not seeing, until his feet hurt. Then he doubled back to take another look at the hand.

It belonged, he decided finally, or didn't belong. He propped the canvas against a wall, face out, replaced it with a new one.

The white oppressed him too. That was nothing new either. He hated the white, warred against it, to the point where sometimes instead of priming his canvases in batches, he prepared them one at a time, just to cheat the white. The white could get to him any time, at the beginning of a cycle before the first image had sprung to life on canvas, or in midstream when the work was supposed to dictate itself. For instance, he knew now what he had to do next, all he had to do was follow the image. The hand was going to reach in from the side, snaking along the ground as if to snatch a column.

Would the fingers cup or close?

He didn't know. He'd have to wait and see.

He supposed vaguely that he'd hit a stretch of diminishing returns in which, as the walls filled with canvases, so did his own inner walls empty. This too was part of his pattern. When the inner walls were bone bare, the cycle ended. He had to move on, or go dead.

He puttered with his plants, and worked a little.

The next morning he was arguing with himself again: to shave or not. He shaved, and brushed his hair before the mirror until it looked the way it had when he'd started. His head seemed lopsided to him. He ran his fingers through the graying bush while he surveyed his wardrobe, imagining combinations. But finally, out of defiance, he chose the paint-smeared coveralls, then, brush in hand, stood by his easel like a dirty immobilized soldier until the Mercedes stopped.

She got out, in a deep blue dress with a single stripe of yellow at one wrist and another below the hips. A broad-brimmed yellow hat hid her hair.

He'd locked the front door. He waited for her knock, then walked to it and opened it. her face.

"Good morning," she said. A faint smile curled into her cheeks, broadening

"Good morning," he said.

She brushed past him. He smelled her smell again, and followed her into his studio.

"Please leave me alone," she said. "I asked you before."

Only the clothes have been changed, he thought, to protect the innocent. But he stood his ground.

"Very well," she said and began to undress before him.

He went to close the drapes.

"Leave them please," she said. "The light's poor enough as it is."

He wasn't used to following instructions. What will the neighbors think, Senora, I'm a law-abiding artist and a poor one, Senora, suppose a photographer happens by with a loaded camera? 
Nevertheless he left the drapes open.

Nude, she studied the canvas he'd propped against the wall. Her hands were at her hips. Daylight caught the twin white melons of her cheeks while her shoulders drifted in shadow. The French fantasy returned. He watched her breasts. Meaty, with brown creased nipples, they lacked the dug look, but judging from the set of her hips she'd borne children. Well-preserved, he thought, our alabaster Senora.

"It will do," she said, "nicely."

Her voice husked at him.

Yes.

He touched her tentatively on the shoulder. Her skin was cool, as he'd expected.

She jerked free of his hand and swerved. Her breasts swung.

"Now you see why I want to be left alone," she said coldly, but her face was empty of anger.

She walked in front of him as if he were the statue, of negligible interest in a gallery of paintings. So he was probably. In front of the easel she adopted the old pose, hands loose by her sides, one foot apart and slightly forward of the other, pale eyes firmly on the canvas, as if framing it.

"I expected you to be further along than this," she said. "With the exposition in three months you have work to do."

"The what?" he asked.

"It's what you wanted, isn't it?"

Her head didn't turn.

"What exposition?"

"Our biennial," she answered casually, still studying the easel. "Isn't that what you wanted? We give it every two years at the museum, for the contemporary American artist. You'll have half a room. My curator will help you make the selection, I've already told him to call you. We'll need twenty canvases to pick from."

She began to dress then, hastily. His mouth stayed half-open in an unuttered sentence while the Frenchman mocked him. The melons slipped into their shroud of beige, their second shroud of blue, their third, also of blue. It seemed such a waste, he thought, why did she bother stripping?

"You'll be busy," she said, "I'll be back Tuesday," and was gone, as before, while he watched, as before, the rear door shut and the black-gloved hands of the chauffeur to the wheel, the white car vanishing. In some crazy way which irritated him he sensed a rightness to the scene, marred only by the instant he'd touched her.

He felt let down and not let down.

Only look, the scene said, mustn't touch.

What did she know that he didn't?

It had nothing to do with what was said, it was physical, an equilibrium of two bodies in fixed and changing postures. It was a dance of nude and . . .

Had he gone completely off his rocker? Equilibrium! The dance of the nude? But he smelled her. You couldn't hallucinate smells. 
"You've got yourself a patron," he said out loud.

He rubbed his hands in parody, then realized he was trembling inside and out, like a kid on the verge. He sucked his breath.

"Coitus interruptus," he murmured. Maybe the chauffeur jazzed her on the way back to Bel Air.

He set to work, though not on the variations he'd need to make up her twenty. The cycle had gaps, cycles always had gaps, and he could fill them drunk or blindfolded. He'd done it before, he'd do it again.

$\mathrm{He}$ had nothing against the Greater Atlantic \& Pacific Biennale either, or whatever they called it. Hell, once he'd sold a painting in Fresno. He wasn't proud. The only difference between a museum and a gallery was that the gallery got a piece of everything, while the museum took its pick of the litter cheap. Equal bastards, take your choice. Both wanted a single image to the product, that's what he'd give them.

Jesus Christ, what did the world expect: for him to kiss its feet for hanging him on a wall?

He painted into the night, attacking the white, all the next day, into the next night and the following day, riding on anger or desperation or some emotion he didn't give a damn about, trying to force it out of him and into the paint, wanting the hand to grab and grab hard. He painted fast and thought he got it right the first time. Yes, the arches collided and didn't collide. Yes, the hand seized and didn't seize. CRAAACK! went the columns in the year 2000 when the hand broke them in two like matchsticks and the arches toppled CRAAACK! when the earth opened up and swallowed all the Greater Atlantic \& Pacific City of the Angels Biennales to its bowels where the core still burned CRAAACK! and then CRAAACK! and then CRAAACK!

He fell asleep finally, slept long, dreaming of La Senora's alabaster cheeks hanging in a vineyard in the California sun. When he woke up and looked at what he'd done, he realized the emotion hadn't left him at all. Not that it made a particle of difference to the work. Once conceived, the work made its own demands, disdaining emotions, took what it wanted, discarded the rest. All he could do was mediate.

The arches arched gracefully. The columns stood tall, and intact.

It looked all right, he guessed. He felt detached from it already, drained and almost empty.

At least he was finished with the hand.

He had his arches to paint once more, old familiars, but in the foreground he wanted columns alone, spare and archless against a scape of brown, tall like ruins in a fog. He thought he might borrow them from Giorgione. Grazie Giorgione, maestro. Only this one picture still hung on his inner walls.

She came on Tuesday as she'd promised, again on Friday. Apparently that was his place in her schedule, between the horseshow and the Gray Ladies' luncheon. 
Each time, hair flecking now red, now gold, she undressed before him and made her royal tour. Each time the bodies crossed, of queen and fool, grazed but did not touch, like pieces in some ethereal chess she'd invented. The balance held.

She was only waiting for the work to end, he sometimes speculated, to reward him with her favor, but suppose he jumped the gun? If she found him nude in the studio, would she really call the chauffeur? What if he showed at the opening in the raw and possessed her, right there, before the astonished multitude? Part and parcel of the esthetic experience! he shouted to Los Angeles, but he realized to his chagrin that no one was watching and none listening other than himself.

Total strangers began to call on him, inspired by the patron. Humbly he heard their halting appreciations and humbly took their checks in his humble abode, sold more of the work than he deserved including some ancients he hated to part with, they'd been with him so long. His Clearance, he called it, Must Liquidate, Moving to New Quarters! In the midst of this goldrush her curator arrived, lisping paleface of a $\mathrm{PhD}$, talking of dynamics and controlled space. Together they selected the canvases, together they discussed placement and framing, interminably, in the grandiose carpeted Egyptian edifice, and she always cool in the background while the curator buzzed like a bee in lavender, followed by photographers from Time and batteries of interviewers, why do you travel so much, sir, are you collecting material, followed by proofs of the poster . . . his Giorgione ... her choice.

In spite of himself, the poster flattered him.

Was that it?

Because she'd stopped coming? Because she'd squeezed him dry like a lemon and thrown him away?

No, he thought angrily, though she had . . . if she had. The work was done, the selection made, his walls half-bare, more, and if she'd found another Contemporary American Artist in need of discovery, what business was it of his?

Besides, he didn't quite believe it.

He liked the poster.

No, if he'd gone flat, it was because the cycle had ended. He always went flat when the cycle ended. The work became so many alien objects. He'd swapped them for a pocketful of dollars, and a fair exchange it was. If he had any mistress, the work was his mistress, and now temporarily he was released and on your way. What was left but to arrange for the shipment and get going? But stripped down, light, lightfooted and, each time he did it, with the butterflies of a stranger in no man's land, because he knew what lay in store for him: the awful strange feeling of the brush in his hand and the stare of white canvas.

So?

So he had a pain in his side, like an inner stitch, something alien which crowded the heart. His pride, he supposed.

So be it.

He stopped dreaming of fruit. One time instead he dreamed of the opening. All he retained of it was the image of the Contemporary American Artists in two 
straight lines like military squads, men on one side in tuxedos, women on the other in the long black gowns of orchestra girls, and he at the end in his coveralls. His dreaming eye craned for a glimpse of her.

He could always call her, but he didn't.

He arrived late and nervous. The Art Temple was awash with bright lights and fancy cars. Perfume dizzied his nostrils and his eyes did a dance with an emerald string. Vaguely he recognized faces out of the newspapers, unnatural without their wax. A Western hero bumped him, he knew the swagger. He saw Big Box Office, stuffed into her jewels like a sausage, in a troop of bearded swains. A barefooted wraith of a starlet glided up to him with a glass-eyed stare. The amalgamated art lovers of the Pacific milled in a mob to meet him, professors and the land rich and the oil rich and their wives in diamonds, while the La Cienega gallery pack yapped at their heels.

His mouth moved without his hearing his own words. Cultured mouths shrieked laughter at him to be replaced by others in the din, while Japanese waiters slid past with silver trays of champagne. He craned his neck, not finding what he sought, and flashbulbs popped.

Suddenly someone was sailing at him out of the crowd.

He hardly recognized her.

Her arm extended. He glimpsed round white flesh. Her cheeks lifted in a vast and winning smile.

People gave way.

He saw her lips move, then her palm joined his in a clasp of equal temperature.

"I've been looking all over for you," she said heartily.

Her red lips roared at him.

"I want you to know, I admire your work enormously."

Behind her head candlelike bulbs winked at him from their sconces. The whole world was laughing at once, squeezing its sides. He felt his shirt sticking to his back. He thought his hair might be on fire.

Abruptly the roaring subsided, the tide receded. His hand was freed, or freed itself without command. His shoulders ached.

"Enormously," the echo of her voice said.

Then the waves pounded back with renewed force. The din rebounded in his ears. She was gone, washed away, replaced by his co-artists who surrounded him in a congratulating phalanx. A painter's painter, he thought distantly. He searched above the sea of heads while hands pumped his hand, but all he saw were the alien objects on the walls, his, staring at nothing.

He didn't find her at all. She must have vanished into the smog. In her place he caught a wide-mouthed tyro from Laguna with wide blue eyes and lips from ear to ear and gold hair which hung to her hips. He seized her by the hair and didn't let go. He got her drunk, and himself, took her home to Potter's Mountain, and he fucked her till the blue rolled out of her sockets. 
The next day, however, the pain returned, intruding foreign body in his body. For all he knew it had always been there, only he'd never noticed. The shippers came for his remaining canvases and went. There was no reason for him to stay, he decided, his rent was paid and his bills, yet he stayed. The gardenias were half-dead. He supposed he ought to revive them for the next tenant. The cactus stood up straight though, they didn't give a damn.

So long, Santa Monica Mountains.

His phone had been disconnected, so twice he went out to call her, no answer, and twice returned. He sat in the dirt backyard with the plants and smoked and watched the moon rise and set.

The third time, though, when he hung up the receiver he kept going. It was morning. He didn't know what he was going to do or say to her, but what the hell, the sun was shining. He rode to Bel Air in style, crossed through the stone gates which separate the rich from the outside chaff. The taxi drove up a lane between white fences and eucalyptus and palms and exotic growths for which he had no name. It stopped by a gate which opened onto manicured grounds and shrubs and, half-hidden up a drive, a white colonial mansion. Only in L.A., he thought, measuring with his eyes the white pillars which held up the portico.

He found a Japanese caretaker playing with a hose.

"They're gone," the caretaker told him, "house closed up."

"Where've they gone?" he asked.

"How do I know?" the caretaker said, grinning from ear to ear. "Where do they go? Acapu'co? Palm Splings?"

For a second he'd half a notion ... but even Palm Splings was the other side of the moon.

"Where do I take us next?" the cab driver asked him, grinning.

"Us," was good. What did the Frenchman do when the museum was empty?

He had no idea, but a few weeks later in another place he began to paint portraits. 